Seminário de Pesquisa

Programa de Pós-Graduação

Design FAU USP

\title{
Uso do tempo em interações de usuários com produtos industriais para realização de tarefas domésticas
}

\author{
Ana Frieda Ávila Nossack, Luís Cláudio Portugal do Nascimento
}

\author{
entrevista remota; design centrado no usuário; rotinas de tarefas \\ domésticas
}

Esta pesquisa busca identificar e analisar diversas formas de manifestação e distribuição da variável "tempo", tal como ocorrem em interações de usuários com equipamentos industrializados, mecanizados ou não, voltados a afazeres domésticos. Propõe-se uma abordagem qualitativa, fenomenológica, construída com base em entrevistas e observações com usuários de tais produtos, na Região Metropolitana de São Paulo, buscando perceber formas de utilização de recursos tecnológicos e funcionais associados a

\section{Curso}

Doutorado

\section{Linha de Pesquisa}

Design: Processos e Linguagens

\section{Ana Frieda Ávila Nossack}

Arquiteta e urbanista, graduada pela Faculdade de Arquitetura e Urbanismo pela Universidade de São Paulo (2007), tem mestrado (2014) também pela FAUUSP.

É professora nas disciplinas de Projeto da FEAU - Univap, em São José dos Campos. Também atua profissionalmente nas áreas de arquitetura e design.

e-mail: frieda.nossack@usp.br

Lattes: http://lattes.cnpq.

br/1437901105257931

\section{Luís Cláudio Portugal \\ do Nascimento}

Professor da FAU USP, doutor em ensino do design pela New York University (1997), mestre pela École Nationale Supérieure d'Arts et Métiers, Paris (1987), e bacharel em desenho industrial e comunicação visual pela Escola Superior de Desenho Industrial da Uerj (1983).

e-mail: claudioportugal@usp.br

Lattes: http://lattes.cnpq.

br/2797773827825547

Orcid: https://orcid.org/0000-

0003-4586-1747 tais equipamentos, à luz da variável "tempo". No atual período de distanciamento social, uma primeira fase de coleta e pré-tratamento de dados está sendo realizada de forma remota, respeitando-se imperativos sanitários. Objetivou-se, por meio do desenvolvimento de uma técnica flexível de coleta de dados (combinando aspectos de entrevistas e questionários, em aplicativos de mensagens), registrar a percepção dos respondentes quanto à duração e qualidade da variável "tempo" no desempenho das tarefas domésticas: limpeza de ambientes, preparo de alimentos, lavagem de roupas e em articulações entre tais atividades, abrangendo suas dimensões físicas, produtivas, sociais e psicológicas. Resultados obtidos até o momento sugerem que esta técnica específica de levantamento remoto se ajustou apropriadamente a esta etapa inicial da pesquisa. Pretende-se complementar o levantamento de dados por meio de outras ferramentas de coleta que permitam explorar aspectos adicionais de situações de uso dos equipamentos. Espera-se contribuir, por fim, para aperfeiçoamento de práticas profissionais de projeto e pedagógicas deste segmento do design voltado a produtos industrializados de utilização doméstica. 


\title{
Use of time in user interactions with industrial products to perform houseworks
}

\author{
Ana Frieda Ávila Nossack, Luís Cláudio Portugal do Nascimento
}

remote interview; user centered design; housework routines

This research seeks to identify and analyze various forms of manifestation and distribution of the variable "time," as they occur in user interactions with industrialized equipment, mechanized or not, which is used for household chores. We propose a qualitative, phenomenological approach based on interviews and observations with users of such products in the Metropolitan Region of São Paulo, seeking to understand ways of using technological and functional resources associated with such equipment, in the light of the variable "time." In the current period of social distancing, a first phase of data collection and pre-treatment is being carried out remotely, respecting health-safety imperatives. The objective was, through the development of a flexible data collection technique (combining aspects of interviews and questionnaires in messaging applications), to record the respondents' perception regarding the duration and quality of the variable "time" in the performance of domestic tasks: cleaning, preparing food, washing clothes, and the

Course

Doctoral

\section{Line of Research}

Design: Processes and Languages

\section{Ana Frieda Ávila Nossack}

Architect and urbanist, graduated from the Fauusp (2007), has a master's degree (2014) also from FAUUSP. She is a teacher in Architecture Projects disciplines at FEAU - Univap, in São José dos Campos. He also works professionally in the areas of architecture and design. e-mail: frieda.nossack@usp.br Lattes: http://lattes.cnpq. br/1437901105257931

\section{Luís Cláudio Portugal \\ do Nascimento}

Professor at FAU USP. He holds a Ph.D. in art education from New York University (1997), a Masters Degree from École Nationale Supérieure d'Arts et Métiers, Paris (1987), and Bachelors Degree in Graphic and Industrial Design from Uerj's Escola Superior de Desenho Industrial (1983)

e-mail: claudioportugal@usp.br

Lattes: http://lattes.cnpq. br/2797773827825547

Orcid: https://orcid.org/00000003-4586-1747 coordination of such activities, including the physical, productive, social and psychological dimensions. The results obtained so far suggest that this specific remote survey technique has been adjusted appropriately to this initial stage of the research. It is intended to complement the data collection through other collection tools that allow exploring additional aspects of equipment usage situations. Finally, we hope to contribute to the improvement of professional design and pedagogical practices in this segment of design aimed at industrialized products for domestic use.

\section{Referências | References}

FLICK, U. 2009. Introdução à pesquisa qualitativa. Porto Alegre: Artmed. GIEDION, S. 2014. Mechanization takes command: a contribution to anonimous history. Mineapolis: University of Minnesota Press.

NASCIMENTO, F. B.; MELLO, J.; LIRA, J. T. C. \& RUBINO, S. 2017. Domesticidade, gênero e cultura material. São Paulo: Centro de Preservação Cultural.

ZANLORENSSI, G. \& GOMES, L. 2020. O aumento por estes ítens na quarentena. NEXO. <https://www.nexojornal.com.br/grafico/2020/05/11/O-aumento-dasbuscas-na-internet-por-estes-itens-na-quarentena>, 3/8/2020. 